International Journal of Engineering \& Technology, $7(4.33)(2018) 228-231$
SPC
International Journal of Engineering \& Technology
Website $w w w . s c i e n c e p u b c o . c o m / i n d e x . p h p / I J E T$
Research paper

\title{
Implementation Analysis on Society-Based Hospital Concept with Software-as-a-Service (SaaS) Technology
}

\author{
Benny Yustim* \\ Informatics Dept, Engineering Faculty, Widyatama University \\ *Corresponding author E-mail: byustim@widyatama.ac.id
}

\begin{abstract}
The high mortality rate of pregnant women in Indonesia due to the low monitoring of their health conditions needs to get special attention from all interested parties. Recording of the development of the health of pregnant women in the Cohort book at the Puskesmas or Clinic is currently only used as a routine when examining pregnant women and has not been used optimally. Data stored in the Cohort book can basically be used as an indicator of the health development of pregnant women, but technology is needed that can monitor and disseminate existing information so that relevant parties can use the information. The application of the concept of Society-Based Hospital, can be one solution for monitoring the condition of pregnant women so that action can be followed up. This concept involves hospitals in a particular area to reduce the limited resources of specialist doctors who are not owned by the Puskesmas or Clinic. The application of the RSBM concept and supported by existing technology, is expected to disseminate information to all relevant parties, so that it can provide rapid action, so as to reduce the high maternal and child mortality rates.
\end{abstract}

Keywords: Pregnant Woman; Cohort book; Society-Based Hospital.

\section{Introduction}

Indonesia is a developing country that has a very large area and some are still areas with inadequate health facilities. The number of public health center service (Puskesmas) and health clinics is not comparable to the number of people. According to the Republic of Indonesia Ministry of Health (RI) report in the 2016 Indonesia Health Profile, there are 9,767 health centers throughout Indonesia and as many as 3,411 are inpatient health centers and 6,356 are inpatients. In the ratio of existing comparisons can be fulfilled for 1 sub-district 1 health center, but there are still some subdistricts that do not have a Puskesmas in the distribution, including in North Kalimantan, Papua and West Papua. The ratio of Puskesmas per sub-district can describe the condition of community accessibility to primary health services. Accessibility of the community is influenced by various factors including geographical conditions, area, availability of basic facilities and infrastructure, and progress of an area. In the province of West Java, the ratio is 1.68 [1].

Each health center or clinic has standardization in recording related to data of patients who come to get services. Each patient will have their respective medical history stored in a patient's medical record. Especially for the health of pregnant women, every progress of the examination carried out is recorded in a cohort book. This book will be used as an indicator of the development of pregnant women.

The Cohort Book is a book that is physically shaped and has a certain storage period. A cohort book is owned by a health center or clinic that organizes maternal and child health (KIA) activities. The physical properties possessed by the Cohort book, resulting in the information contained in the Cohort book being difficult to monitor the condition of the parties involved, unless there is a report from the Health Center or Clinic. This of course can lead to delays in handling and monitoring of pregnant women who have pregnancy problems by related authorities.

Technological developments in Indonesia always keep abreast of technological developments in the global world, but their use in Indonesia is still uneven. The rapid technology is only felt by people in urban areas. This is because there are better infrastructures in urban areas than in rural areas. Not only regional issues, the economic level also determines the use of technology. Most Puskesmas and clinics still do not utilize technology to the full. It would be very risky if the workload related to technology-based resource management is carried out at each Puskesmas or Clinic, because it would require no small amount of money to do so.

The high mortality rate of pregnant women in regions in Indonesia, needs to be of particular concern to related parties. The use of technology needs to be done to facilitate the process of recording and monitoring the condition of pregnant women. The purpose of this study is to 1) analyze the use of technology for storing data on pregnant women so that they can be more easily accessed [2-3], 2) analyzing strategies for disseminating information on the development of maternal conditions for related parties, 3) analyzing Software-as-a-Service system development [7].

\section{Literature Review}

\subsection{Society-Based Hospital / Rumah Sakit Berbasis Masyarakat (RSBM)}

The concept of Community Based Hospital (RSBM) is applied in the City of Cirebon, West Java [4]. This concept adoption utilizes Government and Private Hospitals to conduct certain areas outside the hospital. The form of this coaching is direct service by specialist doctors both those who are promotive, preventive, curative and rehabilitative as well as the transfer of knowledge for health work- 
ers and the community. Institutions involved also include health centers and health education institutions.

\subsection{Health Center Facility}

Health is a basic need for every human being and can be used to achieve his life goals. But, if viewed from a macro perspective, then human health (society), will greatly affect the achievement of the goals set by the government for the country. The government as the policy authority holder, the government needs to be involved in the procurement of health goods / services, so that [8]:

1. Ensure the availability of health goods / services that can be obtained by citizens who need according to their needs;

2. Providing health goods / services for citizens who are unable to meet their needs in the health sector.

Indonesian Government has set Minimum Service Standards (SPM) which are in accordance with the PERMENKES RI no. 75 2014 [5] namely the Puskesmas as the first level health care facility will be the leading unit in the effort to achieve SPM targets. Each Puskesmas is obliged to provide standard antenatal services to pregnant women (RI Ministry of Health Regulation no. 43 2016). Antenatal care is a service provided to pregnant women at least 4 times during pregnancy with a one-time schedule in the first trimester, once in the second trimester and twice in the third trimester conducted by midwives and / or doctors and / or good obstetricians who work at the facility government and private health services that have a Register Certificate (STR). As for the antenatal services themselves, must meet the $10 \mathrm{~T}$ criteria including:

a. Weigh weight and measure height;

b. Measure blood pressure;

c. Value of nutritional status (Measure Upper Arm Circumference / LILA)

d. Measure the height of the peak of the uterus (fundus uteri);

e. Determine fetal presentation and Fetal Heart Rate (FHR);

f. Screen tetanus immunization status and provide Tetanus Toxoid (TT) immunization if needed;

g. Provision of blood tablets of at least 90 tablets during pregnancy;

h. Laboratory tests: Pregnancy test, blood hemoglobin $(\mathrm{Hb})$ examination, blood type examination (if it has not been done before), urine protein examination (if indicated); whose services are adjusted according to the trimester of pregnancy.

i. Management / handling of cases according to authority;

j. $\quad$ Talking (counseling)

Every development of a pregnant woman who is examined at a health center needs to be recorded in a special book. In accordance with [2-3], every antenatal activity carried out will be recorded in a register book called the Mother Cohort book. At present, because of the limitations that exist in recording the cohort book most of the Puskesmas still use books in physical form (paper)

\subsection{Mobile Technology}

Mobile technology is a wireless or portable technology, so it has the ability to be carried and used anytime and anywhere. The ability of this technology is a manifestation of computer technology that is developing so rapidly, so that dimensions can be reduced to the size of human hands. One technology that is currently still widely used in Indonesia is $2 \mathrm{G}$ technology [6], where there is SMS (Short Message Service) technology that can facilitate the delivery of information in the form of text and does not require sophisticated devices to be used in this technology.

\subsection{Cloud Technology}

Rapid technological development and the availability of supporting infrastructure, resulting in the emergence of various needs and innovations to be used to facilitate various business processes that are currently perceived as difficult and require high resources.
Cloud technology itself does not require independent management of the resources needed [7]. There are several concepts that can be offered to users of this service, including:

1. Infrastructure-as-a-Service (IaaS)

Service providers only provide infrastructure that can be utilized by customers for their needs.

2. Platform-as-a-Service (PaaS)

Service providers provide various basic needs that are generally needed by customers, for example Operating System, Storage, Memory and other facilities.

3. Software-as-a-Service (SaaS)

Service providers provide services to certain parties to be able to utilize the platform provided to be developed into a variety of specific forms of services in accordance with business processes. The software developed is then offered as a form of service to users.

\section{Methodology}

With existing conditions, the research activities will use qualitative methods with a case study approach. This approach is expected to provide a real picture of the research subject and can provide the best solution to the problem at hand. The research subjects were Kesunean Health Center and Cirebon City Health Office. The steps and research activities carried out are as follows:

1. Observing the course of activity

2. See the results of recording in the Pregnant Woman's Cohort book.

3. Conduct interviews related to the process of implementing activities, including the obstacles faced and major problems that may exist.

\section{Analysis and Discussion}

\subsection{Cohort Book (Register Book)}

The Cohort Book is a register book that is used in health centers and clinics that provide maternal and child health services. There is various information related to Pregnant Women in broad outline grouped into 3 parts, including:

1. Personal Data of Pregnant Women

This section records the name of the pregnant woman and the name of the husband, address, and age of mother / pregnancy.

2. Initial data related to pregnant women (health condition / illness suffered)

Data on this health condition will be examined carefully in order to see the condition of pregnant women.

3. Inspection data Record information regarding the development of pregnant women every visit to the Puskesmas or clinic.

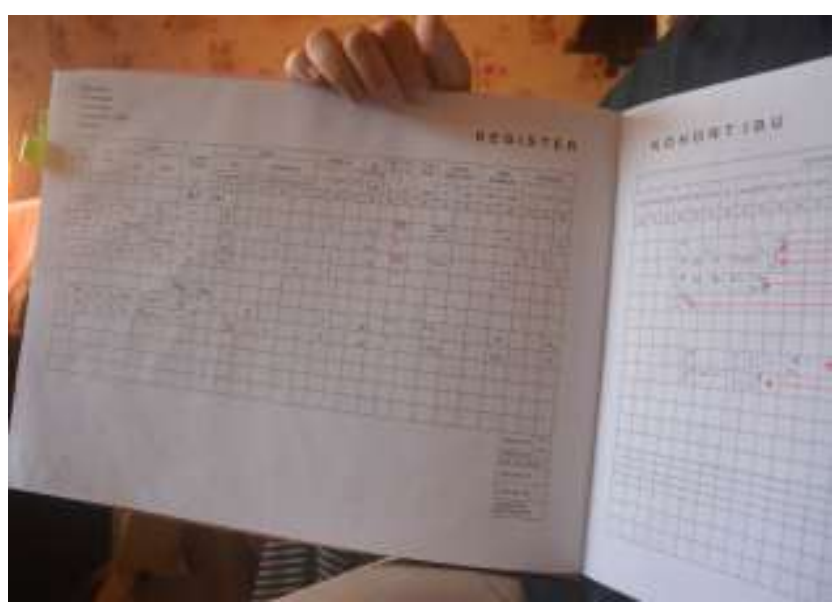

Fig. 1: Mother Cohort Book 
The information is stored in the form of tables as in Figure 1. Pregnant woman data will be stored in 1 record in the book, until the status is obtained by birth status.

\subsection{Information Dissemination of Doctor Specialist Vis- its}

Recording the condition of pregnant women in the cohort book will be reviewed at certain times by the doctor or midwife in the Puskesmas. If there is a problem that might be feared to be an undesirable condition, especially for pregnant women and their fetuses, the Puskesmas will ask for visits from doctor specialist from hospitals in their clusters area. The hospital will provide further information to follow up on requests by the Puskesmas.

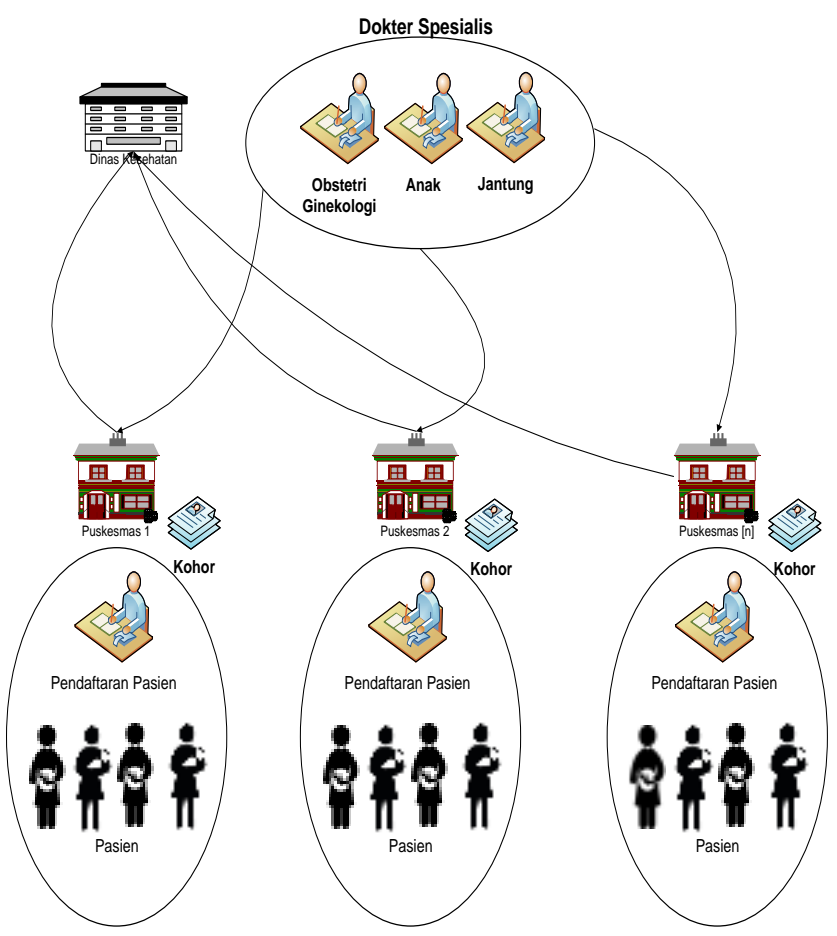

Fig. 2: Information Dissemination

The hospital will respond to the request by sending doctor specialist, usually will be forwarded by the health center to patients who have pregnancy disorders. Problems will appear in the information delivery process. Normally the delivery of this information will be delivered via Short Message Service (SMS), but sometimes the information submitted is often not up to the intended person, due to network problems, the replacement of the number or cell phone is lost. In anticipation of this, cadres in the village or posyandu will be asked for assistance to contact the mother concerned, to be able to attend a doctor's specialist visit to their health center.

\subsection{Software-as-a-Service (SaaS -based System Devel- opment Potential}

Based on the results of the 2017 ICT Usage Survey by the 2017 Ministry of Communication and Information Technology Development Team, it can be seen that around $53.85 \%$ of cell phone users are $2 \mathrm{G}$ technology users, the rest are smartphone users. Whereas in the survey conducted by the HR Research and Development Agency, the Indonesian Ministry of Communication and Information in 2014 there were around 313,226,914 cellular users in 2013 with a growth of around $18 \%$ per year. If this assumption is used then in 2018, cellular users throughout Indonesia will get $845,573,017$ users [6].

The growth of cellular technology users is not comparable with the speed of growth in the use of computer technology or the distribution of supporting infrastructure. Existing limitations do not rule out the possibility of developing SaaS-based technology, so that Puskesmas as customers do not need excessive resources to be able to use this facility.

In Figure 3, there is a model that can be proposed to be used as a basis for system development. This still utilizes technology that has the most widely available availability in Indonesia.

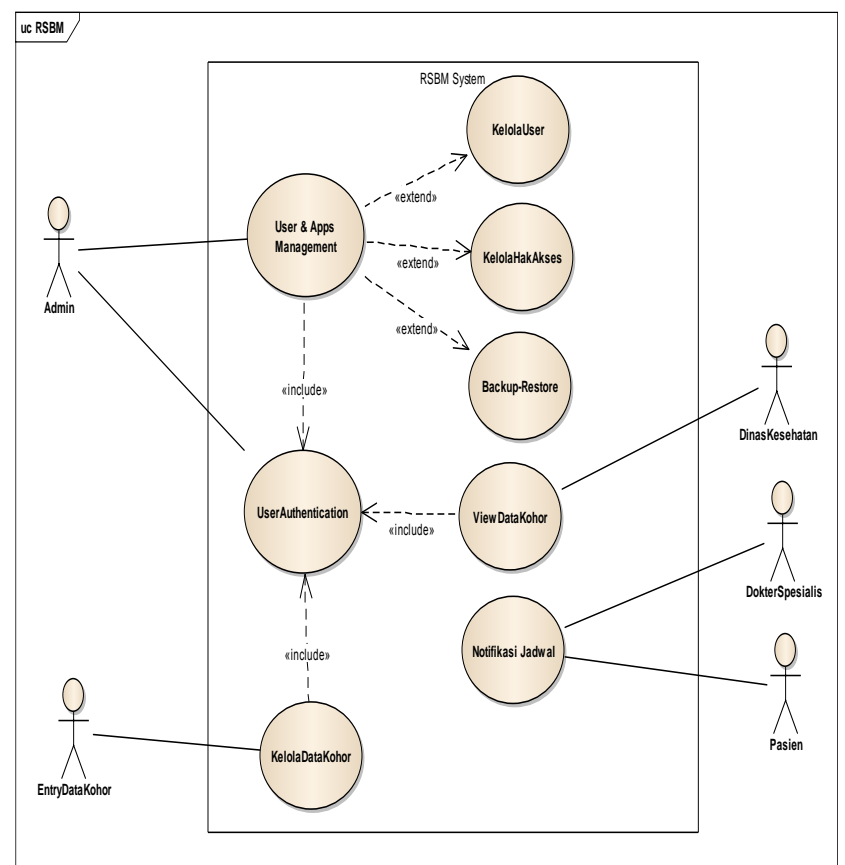

Fig. 3: SaaS-based system development planning

\section{Conclusion}

There are various problems and things that can be discussed to be able to improve the results of this study in the future.

\subsection{Conclusion}

Based on the previous discussion, some results can be concluded:

1. The need for system development to be able to store examination data of pregnant women in accordance with the needs of the current cohort book.

2. Dissemination of information related to the visit of specialist doctors requires the technology that is widely available today namely with the $2 \mathrm{G}$ platform and with the application of the concept of automation.

3. The use of cloud technology with the Software-as-a-Service (SaaS) concept is expected to reduce the gap in the availability of human and technological resources at the Puskesmas, so that it is sufficient to use the system without having to think about the complexity of system development and maintenance.

\subsection{Suggestion}

There are various things that can still be done for the development and sustainability of this research, including:

1. Further studies are needed, whether integration with newer technologies is needed (utilizing smartphones)

2. Need further study to continue to the next development stage (Modeling and Implementation)

3. Utilization of smartphone technology as an alternative to the delivery of information.

\section{References}

[1] Tim Penyusun Kementrian Kesehatan Republik Indonesia. (2016) Profil Kesehatan Indonesia 2016, Katalog Dalam Terbitan. Kementerian Kesehatan RI 
[2] Pedoman Depkes RI. (1981). Pedoman Sistem Pencatatan Pelaporan Terpadu Puskesmas. DepKes RI.

[3] Pedoman Depkes RI. (1993), Pedoman Sistem Pencatatan dan Pelaporan Terpadu Puskesmas, DepKes RI.

[4] Perda Kota Cirebon no 4. (2011), Tentang Sistem Kesehatan Kota Cirebon, Lembaran Daerah Kota Cirebon.

[5] Badan Litbang SDM, Depkominfo RI. (2014).Buku Saku Data dan Tren TIK. Depkominfo RI.

[6] Tim Penyusun Kominfo. (2017). Survey Penggunaan TIK 2017: Serta Implikasinya terhadap Aspek Sosial Budaya Masyarakat Pusat Penelitian dan Pengembangan Aplikasi Informatika dan Informasi dan Komunikasi Publik, Kominfo RI

[7] Mahmood, Z., Erl, T., Puttini, R. (2013). Cloud computing: Concepts, technology and architecture. Prentice Hall.

[8] PERMENKES RI Nomor 43 Tahun 2016. (2016). Standar Pelayanan Minimal Bidang Kesehatan. KEMENKES RI. 